\title{
ON THE PROTECTION AGAINST THE ACTION OF ULTRAVIOLET LIGHT AFFORDED TO ALEXIN AND SENSITIZER BY CERTAIN
SUBSTANCES*
}

\author{
Florence McCoy Hill and Carl L. A. Schmidt \\ From the Department of Biochemistry and Pharmacology of the University of \\ California, Berkeley
}

That ultraviolet light possesses a highly destructive action on various immune bodies - alexin, lysins, agglutinins, toxins and antitoxins, as well as on protoplasm in general, when these substances are exposed either alone or together with certain fluorescent substances ${ }^{1}$ such as eosin and fluorescein, has been known for some time. The investigations of $\mathrm{Huber}^{2}$ and Busck, ${ }^{3}$ and particularly those by Baroni and Jonesco-Mihaiesti ${ }^{4}$ and by Abelin and Stiner ${ }^{5}$ with immune substances bear out this statement. The results indicate that alexin is particularly susceptible to the action of ultraviolet light, and that the time required for complete destruction varies with the thickness of the layer exposed and the serum dilution. More recently the ground has been gone over again by Bovie, ${ }^{8}$ Brooks, ${ }^{7}$ and Sellards ${ }^{8}$ in studying the action of tropical sunlight and results obtained which are essentially in accord with the earlier work.

It has also been noted that the action of ultraviolet light may be inhibited by the addition to the photosensitive substance of blood serum, egg white ${ }^{9}$ and various other protein substances, or when the rays are first passed through a glass instead of a quartz vessel. This

Received for publication June 18, 1919.

* Aided in part by a grant from the George Williams Hooper Foundation for Medical Research.

1 Ledoux-Lebard: Annal. l'Inst. Past., 1902, 16, p. 587; Raab, O.: Ztschr. f. Biol., 1900, 39, p. 524; Raab, O.: Ztschr. f. Biol., 1902, 44, p. 16; von Tappeiner, H, and Jodlbuuer, A.: München. med. Wchnschr., 1904, 51, p. 737 and 1139 ; von Tappeiner, H., and Jodlbauer, A.: Deutsch. Arch. f. klin. Med, 1904, 80, p. 427; Lichtwitz, L.: München. med. Wehnschr. 1904, 51, p. 1589: Pfeiffer, H.: Wien klin. Wchnschr., 1905, 18, pp. 221 and 328; Sacharoff, G., and Sachs, H.: München. med. Wchnschr., 1905, 52, p. 297; Fleischmann, P.: München. med. Wchnschr., 1905, 52, p. 693; Hasselbalch, K. A.: Biochem. Ztschr., 1909, 19, 1. 4.35.

2 Arch. f. Hyg., 1905, 54, p. 53.

s Biochem. Ztschr., 1906, 1, p. 425.

- Compt. rend. Soc. de biol, 1910, 68, p. 393.

5 Ztschr. "f. Immunitätsforsch. w. exp. Therap., 1913, 19, p. 1.

- Jour, Med. Research, 1918, 38, p. 335.

T Jour. Med. Research, 1918, 38, p. 345.

s Jour. Med. Research, 1918, 38, p. 293.

9 Henri, V., and Wurmser, R.: Compt. rend. Soc. de biol., 1912, 73, p. 319. 
protective action is due to the absorption of the ultraviolet rays by the protecting agent. Soret ${ }^{10}$ has shown that most proteins exhibit an absorption band in the ultraviolet end of the spectrum and that solutions of tyrosin exhibit this phenomenon most markedly. Kober ${ }^{11}$ carried out spectrographic investigations on various amino-acids and split products of protein hydrolysis, and found that with the exception of the aromatic amino-acids, tyrosin and phenylalanin, the amino-acids, like the aliphatic acids, esters and certain other compounds investigated by. Bielecki and Henri, ${ }^{12}$ show no specific absorption. In the instance of the two mentioned aromatic amino-acids, the absorption is very marked and leads one to believe that the protective action afforded by certain proteins is due to their content of these amino-acids.

Harris and Hoyt, ${ }^{13}$ working in this laboratory, have confirmed these general results by studying the protection afforded to paramecia and certain bacteria by tyrosin and several other substances against the toxic action of ultraviolet light. It was this work that led to the present investigation which has for its object a more detailed study of aromatic substances as protecting agents against ultraviolet light. To measure this action we have chosen to work with alexin and the sensitizer for sheep cells, components of the well known hemolytic system, since these substances are easily measured, are very susceptible to the action of ultraviolet light, and exhibit moreover a difference in susceptibility toward these rays as well as toward heat. By determining the amount of either alexin or sensitizer to just cause complete hemolysis of the sheep cells, the amount of destruction due to exposure to the light as well as the protection afforded by various substances can be easily determined.

As a source of ultraviolet light we employed a Cooper-Hewitt-type Zquartz mercury arc lamp, the tube being about $12 \mathrm{~cm}$. above the solution to be tested for protective power. The latter was measured into quartz beakers mounted on black cardboard so that only the light passing through this solution could act on the serum contained in a shallow glass dish packed in ice. In the experiments on alexin, pooled guinea-pig serums were used in a dilution of $1: 10$ and sensitizer standardized in terms of alexin $(0.1 \mathrm{cc})$, two units of the latter being used for the hemolytic system. In carrying out experiments with sensitizer, two serums were used, designated as $A(1: 9,500)$ and $B(1: 2,000)$ and the dilutions kept constant as originally standardized against alexin.

10 Arch. d. Sc. phys. et nat., Geneva, 1878, p. 322, and 1883, p. 194.

11 Jour, Biol, Chem, 1915, 22, p. 433.

12 Compt. rend. Acad. d. sc., 1912, 155, pp. 456, 1617; 1913, 156, pp. 550, 884, 1860; 157, p. 372; Berichte, 1912, 45, p. 2819; 1913, 46, p. 1304. See also, Baly, E. C. C., and Desch, C. H.: Jour. Chem. Soc. London, 1904, 85, p. 1029.

${ }^{13}$ Sc., N. S., 1917, 46, p. 318; Univ. Cal. Pub. Path., 1919, 2, p. 245. 
Table 1 shows the time required for destruction of alexin and sensitizer, absence of hemolysis indicating destruction. It will be noted that the unit of sensitizer is more easily destroyed than the unit of alexin, although a longer time is required for the lower (serum $B$ ) than for the higher dilution (serum A). The unit of sensitizer is, however, the same in both cases, and it is therefore probable that the protection afforded to $B$ is due to the greater concentration of serum

TABLE 1

(a) Showing Time Necessary ro Destroy Alexin and Rabait vs. Sherp Cele Senstiuzer by Exposure to Ultraviolet Light

\begin{tabular}{|c|c|c|c|c|c|c|}
\hline \multirow[t]{2}{*}{ Substance Fxposed } & \multirow[t]{2}{*}{$\begin{array}{c}\text { Time of } \\
\text { Exposure, } \\
\text { Minutes }\end{array}$} & \multicolumn{5}{|c|}{$\begin{array}{l}\text { Regult } \\
\text { Degree of hemolysis is fndicated by }+,++,+++ \text {. } \\
\text { Inhibition of hemolysis indicates destruction of } \\
\text { alexin or sensitizer. } 0.2 \text { c ceach of alexin and } \\
\text { sensitizer used in the hemolytic system. }\end{array}$} \\
\hline & & $0.0 \mathrm{ec}$ & $0.2 \mathrm{cc}$ & $0.3 \mathrm{c} \mathrm{c}$ & $10.4 \mathrm{ec}$ & $0.5 \mathrm{cc}$ \\
\hline Alexin $1: 10 \ldots \ldots \ldots \ldots \ldots$ & $\begin{array}{l}2 \\
4 \\
6\end{array}$ & $=$ & $\begin{array}{c}++ \\
-\end{array}$ & $\begin{array}{c}++t \\
-\end{array}$ & $\begin{array}{c}++ \\
+ \\
+\end{array}$ & $\begin{array}{c}++ \\
++ \\
+\end{array}$ \\
\hline Sensitizer "A" 1:9,500..... & $\begin{array}{l}1 \\
2 \\
3\end{array}$ & $\overline{-}$ & $\stackrel{++}{=}$ & $\begin{array}{c}++ \\
-\end{array}$ & $\begin{array}{c}+++ \\
++ \\
-\end{array}$ & $\begin{array}{l}+++ \\
++t \\
+\end{array}$ \\
\hline Sensitizer " $B$ " $1: 2,000 \ldots$. & $\begin{array}{l}3 \\
4 \\
5\end{array}$ & $\bar{z}$ & E & \pm & $\stackrel{++}{=}$ & $\begin{array}{l}++ \\
+\end{array}$ \\
\hline $\begin{array}{l}\text { Sensitizer " } B \text { " } 1: 10 \ldots \ldots \ldots \\
\text { After exposure diluted" } \\
1: 2,000 \text { for hemolytic } \\
\text { system }\end{array}$ & $\begin{array}{l}30 \\
45 \\
60\end{array}$ & 二 & E & $\frac{ \pm}{-}$ & $\begin{array}{l}++ \\
+ \\
-\end{array}$ & $\begin{array}{l}++ \\
++ \\
+\end{array}$ \\
\hline
\end{tabular}

(b) Protection Afforded to Alexin and Sensitizer by the Homologous Serum (INACTIVATED)

\begin{tabular}{|c|c|c|c|c|c|c|}
\hline \multirow{2}{*}{ Protecting Substance } & \multirow{2}{*}{$\begin{array}{l}\text { Timo of } \\
\text { Exposure, } \\
\text { Minutes }\end{array}$} & \multicolumn{5}{|c|}{ Result } \\
\hline & & $0.0 \mathrm{ec}$ & $0.2 \mathrm{ec}$ & $0.3 \mathrm{cc}$ & $0.4 \mathrm{ec}$ & $0.5 \mathrm{cc}$ \\
\hline Alexin $1: 10 \ldots \ldots \ldots \ldots \ldots$ & $\begin{array}{l}30 \\
45\end{array}$ & - & + & $\begin{array}{c}++ \\
+\end{array}$ & $\begin{array}{c}+++ \\
++\end{array}$ & $\begin{array}{c}++t \\
++\end{array}$ \\
\hline Sensitizer " $B$ " $1: 10 \ldots \ldots \ldots$ & $\begin{array}{l}30 \\
45\end{array}$ & $=$ & - & \pm & $\begin{array}{c}++ \\
+\end{array}$ & $\begin{array}{l}++ \\
++\end{array}$ \\
\hline
\end{tabular}

proteins. While the unit of sensitizer as compared with that of alexin is apparently more readily destroyed, yet alexin is actually more susceptible to the action of ultraviolet light than sensitizer. The apparent differences are due to dilution. When sensitizer in equivalent dilution (1:10) is exposed to ultraviolet rays 1 hour is required for complete destruction of the unit, while for alexin complete destruction takes place in about 5 minutes. The comparison between alexin and sensi- 
tizer in equivalent dilutions is only approximate, since the time for destruction depends on the concentration of serum proteins which in the instance of the rabbit ${ }^{14}$ and the guinea-pig ${ }^{15}$ is different. Measured in terms of protective action the serums are not markedly different, as shown in the second part of table 1. The protective action of alexin and sensitizer in equivalent dilutions (both having been inactivated at $56 \mathrm{C}$.) for the homologous immune body was determined. Although alexin has been destroyed, the serum still possesses marked protective action, or in other words, ability to absorb ultraviolet rays.

TABLE 2

Showing Protection of Alexin gy Various Substances When Exposed to the Action of Ultraviolet LigitT

\begin{tabular}{|c|c|c|c|c|c|c|c|}
\hline \multirow[t]{2}{*}{$\begin{array}{l}\text { Substance and } \\
\text { Concentration }\end{array}$} & \multirow[t]{2}{*}{ Soivent } & \multirow[t]{2}{*}{$\begin{array}{l}\text { Time } \\
\text { of Ex- } \\
\text { posure, } \\
\text { Minutes }\end{array}$} & \multicolumn{5}{|c|}{$\begin{array}{c}\text { Result } \\
\text { Degrce of hemolysis is indicated by } \\
+,++,+++ \text { Inhibition of } \\
\text { hemolysis indicates destruetion } \\
\text { of ulexin. } 0.2 \mathrm{ce} \text { alexin }=\mathbf{2} \text { units. }\end{array}$} \\
\hline & & & $0.0 \mathrm{cc}$ & $0.2 \mathrm{c} \mathrm{e}$ & $0.3 \mathrm{c} \mathrm{c}$ & $0.4 \mathrm{ce}$ & $0.5 \mathrm{ce}$ \\
\hline 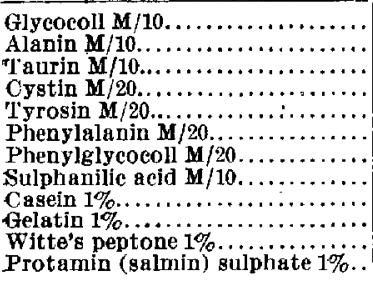 & \begin{tabular}{|c|}
$\mathrm{N} / 10 \mathrm{KOH}$ \\
$\mathrm{H} 20$ \\
$\mathrm{~N} / 10 \mathrm{KOH}$ \\
$\mathrm{N} / 10 \mathrm{HOl}$ \\
$\mathrm{N} / 10 \mathrm{KOH}$ \\
$\mathrm{N} / 40 \mathrm{NH} \mathrm{HOH}_{4}$ \\
$\mathrm{~N} / 20 \mathrm{KOH}$ \\
$\mathrm{H}_{2} \mathrm{O}$ \\
$\mathrm{N} / 10 \mathrm{KOH}$ \\
$\mathrm{H}_{20}$ \\
$\mathrm{H}_{2} \mathrm{O}$ \\
$\mathrm{H}_{2} \mathrm{O}$
\end{tabular} & $\begin{array}{l}15 \\
15 \\
15 \\
15 \\
90 \\
90 \\
90 \\
90 \\
90 \\
15 \\
90 \\
30 \\
45\end{array}$ & $\begin{array}{l}\overline{-} \\
\bar{z} \\
\pm \\
\bar{z} \\
= \\
=\end{array}$ & $\begin{array}{c}- \\
z \\
\overline{-} \\
++ \\
+++ \\
++ \\
+++ \\
++ \\
+++ \\
++ \\
+\end{array}$ & $\begin{array}{l}\overline{-} \\
\overline{+} \\
+ \\
+++ \\
+++ \\
++ \\
+++ \\
+++ \\
+++ \\
++\end{array}$ & $\begin{array}{l}\overline{-} \\
\overline{+} \\
+\dot{+} \\
+++ \\
++t \\
+++ \\
+++ \\
+++ \\
+++\end{array}$ & $\begin{array}{l}++ \\
+ \\
++ \\
+++ \\
+++ \\
+++ \\
+++ \\
+-+ \\
+++ \\
+++\end{array}$ \\
\hline $\begin{array}{l}\text { Amino benzoic acid } \mathbf{M} / 10 \ldots \ldots \ldots \ldots \\
\text { Sodium benzoate } \mathbf{M} / 10 \ldots \ldots \ldots \ldots \ldots \\
\text { Benzole acid } \mathbf{M} / 10 \ldots \ldots \ldots \ldots \ldots \ldots \\
\text { Anilin } 1 \% \ldots \ldots \ldots \ldots \ldots \ldots \ldots \ldots \ldots\end{array}$ & $\begin{array}{l}\mathrm{H}_{2} \mathrm{O} \\
\mathrm{H}_{2} \mathrm{O} \\
\mathrm{H}_{2} \mathrm{O} \\
\mathrm{H}_{2} \mathrm{O}\end{array}$ & $\begin{array}{l}90 \\
90 \\
90 \\
90\end{array}$ & $\overline{-}$ & $\begin{array}{l}++ \\
++ \\
+++ \\
+++ \\
+++\end{array}$ & $\begin{array}{l}+++ \\
+++ \\
+++ \\
+++\end{array}$ & $\begin{array}{l}++t \\
+++ \\
+++ \\
+++\end{array}$ & 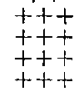 \\
\hline
\end{tabular}

We next measured the protective power of various amino-acids, proteins, and certain substances of the aromatic series, the results being summarized in tables 2 and 3 . The time of exposure as given is exclusive of the time necessary for destruction of immune body when the solvent alone is used as protecting agent.. Proper controls were run to insure uniformity of conditions and destruction of immune body without protecting solution. It will be noted that alanin, glycocoll, taurin, and gelatin have little or no protective action against the destructive action of ultraviolet light. Marked protection is, however, shown by the aromatic amino-acids, tyrosin and phenylalanin and also

14 Woolsey, J. H.: Jour. Biol. Chem., 1913, 14, p. 433.

1s Wells, C. E.: Jour. Biol. Chem., 1913, 15, p. 37. 
by various substances of the aromatic series. Casein and Witte's peptone both protect. It was expected that protamin (salmin) sulphate, due to its almost complete lack of aromatic amino-acids, would show no protective action; however, on testing our preparation, a positive test for tyrosin was obtained. This was true also for the preparation of cystin used. The results also show that the benzol ring is the determinatve factor and not the groups attached to the ring. Thus anilin, benzoic acid, and sulphanilic acid protect equally well. The protection afforded by casein and the absence of any protective action shown by gelatin is due to the difference of aromatic aminoacid content, gelatin. lacking these.

TABLE 3

Showing Protection of Rabit vs. Sheep Cell Sensitizer by Various Substances Whej Fxpoised to the Action of Ultraviolet Light

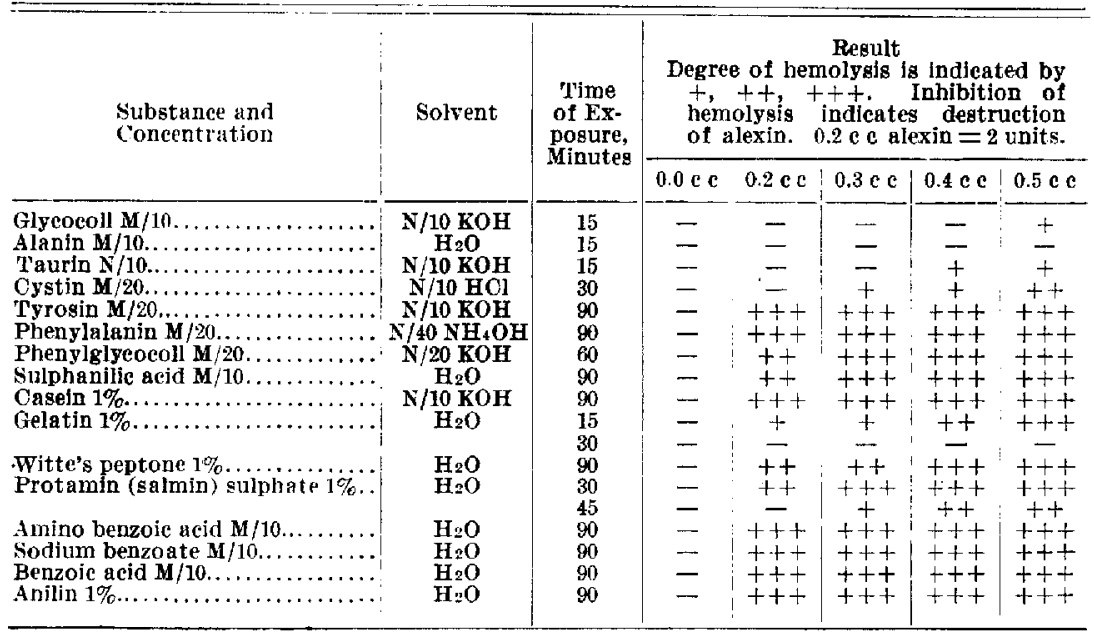

Note: In the first three determinations sensitizer " $A$ " $(1: 9,500)$ was used. In the others sensitizer " $B$ " $(1: 2,000)$ was used.

It is a fundamental concept in photochemistry that action by light cannot take place without absorption. Since absorption in proteins is largely due to the content of aromatic amino-acids it would seem to follow that in the case of substances such as the immune bodies, destruction is due to the content of aromatic amino-acids, unless the action be secondary as in the instance of leucin noted by Harris and Hoyt. ${ }^{13}$ It is possible that the difference in susceptibility shown by alexin and sensitizer is due to a difference in aromatic amino acid content. 
SUMMARY

Although the unit of sensitizer is more easily destroyed by exposure to ultraviolet light than the unit of alexin, the difference is not real, since the concentration of serum proteins is enormously different. In dilutions more nearly comparable alexin is more quickly destroyed than sensitzer.

The aromatic amino-acids, tyrosin and phenylalanin, proteins containing these amino acids and certain substances belonging to the aromatic series show marked protective action for alexin and sensitizer against the action of ultraviolet rays.

Since destruction cannot take place without absorption it is possible that the difference in susceptibility shown by alexin and sensitizer toward ultraviolet light is due to a difference in aromatic amino-acid content. 